\title{
THE ENCHYTRAEID FAUNA (ENCHYTRAEIDAE, CLITELLATA) OF THE RAX MOUNTAIN (AUSTRIA) WITH DESCRIPTION OF TWO NEW SPECIES AND COMPARISON OF FRIDERICIA DISCIFERA HEALY, 1975 AND F. ALPICA SP. N.
}

\author{
KLÁra Dózsa-FARKas ${ }^{1}$ and TAMÁs Felföldi ${ }^{2}$ \\ ${ }^{1}$ Department of Systematic Zoology and Ecology, Eötvös Loránd University \\ H-1117 Budapest, Pázmány Péter sétány 1/C, Hungary; E-mail: kdozsafarkas@gmail.com \\ ${ }^{2}$ Department of Microbiology, Eötvös Loránd University \\ H-1117 Budapest, Pázmány Péter sétány 1/C, Hungary; E-mail: tamas.felfoldi@gmail.com
}

The enchytraeid fauna of the Rax mountain range (Austria) was investigated. Samples were taken from five different habitats: under Pinus mugo, under Picea abies, under Larix decidua, from a mixed forest (P. abies with Betula pendula) and from an alpine meadow. Forty one enchytraeid species belonging to 12 genera were found and additionally the terrestrial polychaete Hrabeiella periglandulata. In addition to the very frequent species, Fridericia discifera Healy, 1975, another species with very similar spermathecae but differing in some traits was also observed. The characters which could be used to discriminate this new species, F. alpica sp. n. from F. discifera are discussed in this paper. Another species collected from the study site, F. raxiensis sp. n. was also new to science and is described based on both morphological and molecular taxonomic methods.

Keywords: enchytraeid fauna, new Fridericia species, molecular analysis, Rax Mountain.

\section{INTRODUCTION}

The enchytraeid fauna of the Austrian Alps is still little known. SchmidegG (1938) reported 14 species from Northern Tirol. However, the true identity of several species given in that study is uncertain, as was pointed out by SCHMELZ (2003). Nurminen (1977) reported 32 enchytraeid species from Grossglockner. Later, BAUER (1993, 1996a, b, 1998 and BAUER et al. 1994) reported 21 species from spruce forests, subalpine meadows and pasture in Central Alps, in the Northern Limestone Alps and Eastern Austria. Subsequently, for frost survival experiments, she studied the enchytraeid fauna and the abundance of enchytraeids on the Rax plateau in a subalpine meadow, where she found 12 species (BAUER 2002a, b).

In 2012, we started an investigation focusing on the enchytraeid fauna of the Köszeg Mountains (Günzer Mountains) of Hungary and Austria. To compare these subalpine areas and the Rax mountain range, soil samples were taken between 2012-2016 from the upper terminal of the Rax cable car and from the western side of the mountain. Besides, some soil samples were collected in 2008 and sent to us by Roswitha BAuER. In this paper, faunistic 
results and the description of two new species, Fridericia raxiensis sp. n. and F. alpica sp. n. are presented, furthermore a detailed comparison between two similar species, F. discifera and F. alpica sp. n., is also given. The morphological studies were supplemented with molecular taxonomical analyses targeting the nuclear ribosomal ITS region, the mitochondrial cytochrome c oxidase subunit I (CO1) gene and the nuclear histone $3(\mathrm{H} 3)$ gene.

\section{MATERIAL AND METHODS}

Study area - Rax Mountain, Lower Austria. Soil samples were taken from the upper terminal of the Rax cable car and from various habitats at the western side of the mountain, the bedrock is calcareous, pH 5-5.5 (Bauer 2002a). Leg. K. Dózsa-Farkas, J. Farkas \& Z. Tóth (years 2012-2016), and R. Bauer (year 2008):

- $\quad$ subalpine meadows (4 samples): $47^{\circ} 43.172 \mathrm{~N}, 15^{\circ} 45.218 \mathrm{E}, 1613 \mathrm{~m}$ a.s.l.; $47^{\circ} 43.001 \mathrm{~N}$, $15^{\circ} 45.403 \mathrm{E}, 1621 \mathrm{~m}$ a.s.l., (15.05.2012), $47^{\circ} 43.088 \mathrm{~N}, 15^{\circ} 45.365 \mathrm{E} 1584 \mathrm{~m}$ a.s.l. (22.05.2014); $47^{\circ} 41.138 \mathrm{~N}, 15^{\circ} 42.542 \mathrm{E}, 1331 \mathrm{~m}$. a.s.l. (13.05.2016).

- $\quad$ under Pinus mugo (7 samples): 47ำ $71.666 \mathrm{~N}, 15^{\circ} 77.305 \mathrm{E}, 1613 \mathrm{~m}$ a.s.l (10.06.2008). $47^{\circ} 43.233 \mathrm{~N}, 15^{\circ} 45.164 \mathrm{E}, 1612 \mathrm{~m}$ a.s.l.; $47^{\circ} 43.125 \mathrm{~N}, 15^{\circ} 45.277 \mathrm{E}, 1619 \mathrm{~m}$ a.s.l; $47^{\circ} 43.036 \mathrm{~N}, 15^{\circ} 46.024 \mathrm{E}, 1620 \mathrm{~m}$ a.s.l (15.05.20012); $47^{\circ} 42.590 \mathrm{~N}, 15^{\circ} 45.413 \mathrm{E} 1622 \mathrm{~m}$ a.s.l.; $47^{\circ} 43.067 \mathrm{~N} ; 15^{\circ} 46.073 \mathrm{E} 1630 \mathrm{~m}$ a.s.l. (22.05.2014); $47^{\circ} 43.007 \mathrm{~N}, 15^{\circ} 45.401 \mathrm{E}, 1613$ $\mathrm{m}$ a.s.1. (15.05.2015).

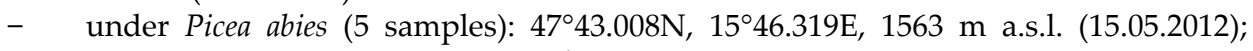
$47^{\circ} 43.012 \mathrm{~N}, 15^{\circ} 46.317 \mathrm{E} 1560 \mathrm{~m}$ a.s.l. $(22.05 .2014,15.05 .2015) ; 47^{\circ} 41.055 \mathrm{~N}, 15^{\circ} 42.561 \mathrm{E}$, $1308 \mathrm{~m}$ a.s.l.; $47^{\circ} 40.537 \mathrm{~N}, 15^{\circ} 43.006 \mathrm{E}, 1260 \mathrm{~m}$ a.s.l. (13.05.2016).

- $\quad$ under Larix decidua (1 sample): $47^{\circ} 41.094 \mathrm{~N}, 15^{\circ} 42.560 \mathrm{E}, 1314 \mathrm{~m}$ a.s.l. (13.05.2016).

- $\quad$ from mixed forest (Picea abies + Betula pendula) (1 sample): $47^{\circ} 40.538 \mathrm{~N}, 15^{\circ} 43.140 \mathrm{E}$, $1116 \mathrm{~m}$ a.s.l. (13.05.2016).

Morphological methods - About $15 \times 15 \times 10 \mathrm{~cm}$ soil sample has been dug (no quantitative sampling). Animals were extracted from the soil by the wet funnel method (O'Connor 1962). Worms were first studied and measured alive, and subsequently preserved in $70 \%$ ethanol. Later, a part of the adult specimens was stained with borax-carmine then passed through an ethanol (70\% to absolute) dehydration series, mounted temporarily in clove oil, and mounted in Euparal between two coverslips. The important morphological structures were recorded in vivo, drawn and photographed using an Axio Imager. A2 microscope with DIC (differential interference contrast) illumination and an AxioCam MRc 5 (Zeiss) digital camera with Axiovision software. The whole-mounted specimens were reinvestigated and also photographed. Selected materials were catalogued with collection numbers for the holotypes ("F"), paratypes ("P") and with slide numbers, and were deposited in the collection of the Department of Systematic Zoology and Ecology, Eötvös Loránd University (Budapest, Hungary).

Methods of molecular analysis - Genomic DNA was extracted from the individuals with the DNeasy Blood \& Tissue Kit (Qiagen) following the instructions given by the manufacturer. Three different regions were amplified with PCR: the mitochondrial cytochrome c oxidase subunit I (CO1) gene, the nuclear histone $3(\mathrm{H} 3)$ gene and the nuclear ribosomal ITS region using the primers HCO2198 (5'-TAA ACT TCA GGG TGA CCA AAA AAT CA-3') and LCO1490 (5'-GGT CAA CAA ATC ATA AAG ATA TTG G-3') (Folmer et 
al. 1994), H3a-F (5'-ATG GCT CGT ACC AAG CAG ACV GC-3') and H3a-R (5'-ATA TCC TTR GGC ATR ATR GTG AC-3') (Colgan et al. 1998), and ETTS1 (5'-TGC TTA AGT TCA GCG GGT-3') and ETTS2 (5'-TAA CAA GGT TTC CGT AGG TGA A-3') (Kane \& Rollinson 1994), respectively. PCRs were performed applying the parameters given by Dózsa-Farkas \& Felföldi (2015). If amplification failed in the case of the H3 gene, two additional primer sets (designed by AllGenetics, A Coruña, and used here with permission of ECT Oekotoxikologie $\mathrm{GmbH}$, Flörsheim) were applied: H3a-new-F (5'-TGG CTC GTA CCA AGC AGA CSG-3') with H3a-new-R (5'-ATG ATG GTG ACG CKY TTG GC-3'), and H3FridM13F (5'-GTA AAA CGA CGG CCA GTT ACC AAG CAG ACG GCH CGY-3') with H3Frid-M13tR (5'-GCG GAT AAC AAT TTC ACA CAG GGG CGT GAA TBG CRC ACA GGT-3') as described in Dózsa-Farkas et al. (2015). Purification and sequencing of PCR products were performed by LGC Genomics GmbH (Berlin, Germany). Removal of primer sequences and manual correction of automatic base calling on chromatograms were carried out using the Chromas software v. 1.45 (Technelysium). Phylogenetic analyses (which included the search for the best-fit models) were conducted with the MEGA 6.0 software (TAmura et al. 2013). Sequences determined in this study were deposited in GenBank under the accession numbers KX985868- KX985875 (ITS), KX985876-KX985884, MG921590 (CO1) and KX985885-KX985896 (H3).

\section{RESULTS}

Forty one enchytraeid species were recorded, representing 12 genera, and additionally one terrestrial polychaeta, Hrabeiella periglandulata (Table 1). Two Fridericia species are considered new to science, namely F. alpica sp. n. and F. raxiensis sp. n., and described below. Two other Fridericia species, be-

Table 1. List of recorded species and their distribution in the investigated habitats of the

\begin{tabular}{|c|c|c|c|c|c|}
\hline \multicolumn{6}{|c|}{ Rax Mountain (Austria) } \\
\hline & meadow & $\begin{array}{l}\text { Pinus mugo } \\
\text { stands }\end{array}$ & $\begin{array}{l}\text { Picea abies } \\
\text { stands }\end{array}$ & $\begin{array}{l}\text { Larix decidua } \\
\text { stand }\end{array}$ & $\begin{array}{l}\text { mixed } \\
\text { forest }\end{array}$ \\
\hline Achaeta danica? & & + & + & & \\
\hline Buchholzia appendiculata & & + & + & & \\
\hline B. fallax * & & & + & & \\
\hline B. simplex* & + & + & + & & + \\
\hline Euenchytraeus clarae & & + & + & & \\
\hline Chamaedrilus cognettii & & + & & & \\
\hline Ch. chlorophilus * & & + & + & & \\
\hline Enchytraeus buchholzi s.l. * & & + & + & & + \\
\hline E. norvegicus & + & + & + & & \\
\hline E. bulbosus & & & & + & + \\
\hline Enchytraeus sp. & & & & & + \\
\hline Enchytronia christenseni & & + & & & \\
\hline
\end{tabular}


Table 1 (continued)

\begin{tabular}{|c|c|c|c|c|c|}
\hline & meadow & $\begin{array}{l}\text { Pinus mugo } \\
\text { stands }\end{array}$ & $\begin{array}{l}\text { Picea abies } \\
\text { stands }\end{array}$ & $\begin{array}{l}\text { Larix decidua } \\
\text { stand }\end{array}$ & $\begin{array}{l}\text { mixed } \\
\text { forest }\end{array}$ \\
\hline En. parva & & + & + & & \\
\hline En. baloghi & & & + & & \\
\hline Fridericia alpica sp.n. & + & + & + & & \\
\hline F. aurita s.1.1* & & + & + & + & + \\
\hline F. aurita s.1.2 & & & & + & \\
\hline F. benti & & + & & & \\
\hline F. bisetosa & & + & & + & \\
\hline F. connata & + & + & + & & \\
\hline F. discifera & & + & + & & + \\
\hline F. galba & & & + & & + \\
\hline F. miraflores & & & + & & \\
\hline F. paroniana & & + & & & \\
\hline F. perrieri & & & & & + \\
\hline F. raxiensis sp.n. & + & + & & & \\
\hline F. semisetosa & & & & & + \\
\hline F. tubulosa & + & & & + & \\
\hline F. waldenstroemi & & & & & + \\
\hline Fridericia sp. & & & & & + \\
\hline Hemifridericia parva & + & + & & & \\
\hline Henlea glandulifera & & + & + & & \\
\hline H. heleotropha & + & & & & \\
\hline H. perpusilla* & + & + & & + & + \\
\hline H. nasuta & & + & + & & \\
\hline Marionina argentea s.l. * & & + & & & \\
\hline M. communis & + & & & & \\
\hline Mesenchytraeus armatus & & + & & & \\
\hline Me. glandulosus & + & & & & \\
\hline Me.pelicensis & & + & & & \\
\hline Oconnorella cambrensis & & + & & & \\
\hline $\begin{array}{l}\text { Total number of en- } \\
\text { chytraeid species: } 41\end{array}$ & 11 & 26 & 18 & 6 & 12 \\
\hline Hrabeiella periglandulata & & + & + & & \\
\hline
\end{tabular}

* species found previously by BAUER $(2002 a, b)$ too 
longing to the F. aurita species complex are listed as F. aurita sensu lato 1 and 2, while an additional Fridericia species represents probably another new species (F. sp.). Moreover, one undescribed Enchytraeus species was found but its identity requires further studies. The list of recorded species and their distribution in the investigated habitats are given in Table 1 . Seven enchytraeid species were found on the Rax Mt. previously by BAUER $(2002 a, b)$ too (marked with * in Table 1). In Table 1, Chamaedrilus chlorophilus (after Martinsson et al. 2015) is surely identical with Cognettia sphagnetorum found by BAUER. Two species recorded by her, F. ratzeli and Stercutus niveus, were not found in our study. The possible reason for the absence of $S$. niveus, is that this species occurs at the surface only in autumn and winter, from April or May until July or August, without feeding, they retreat to the deeper layers of the soil and aggregate into smaller groups (DózsA-FARKAs 1973), and we collected the soil only in summer so this species did not came to the samples, contrary BAUER collected her worms also in September and December.

\section{DESCRIPTIONS OF THE NEW SPECIES Fridericia alpica sp. $\mathrm{n}$. (Figs 1-2)}

Type material - Holotype. F. 26. slide No. 2136, Rax Mountain, close to the Rax cable car terminal, under Pinus mugo $47^{\circ} 43.233$ N, 1545.164E, $1612 \mathrm{~m}$ a.s.l., 15.05.2012.

Paratypes. In total 13 specimens. P.110.1.1. slide No. 2137 at the type locality.15.05.2012; P.110.1.2-110.1.3, slides No. 2120, 2156, two specimens on Rax Mountain at the type locality, under Pinus mugo, $47^{\circ} 43.038 \mathrm{~N}, 15^{\circ} 46.024 \mathrm{E}, 1623 \mathrm{~m}$ a.s.l. and $47^{\circ} 43.007 \mathrm{~N}, 15^{\circ} 45.401 \mathrm{E}$, 1613 m a.s.l., 22.05.2014; P.110.1.4-109.1.6 slides No. 2129, 2132-2133, three specimens, on Rax Mountain, near to type locality under Picea abies $47^{\circ} 43.012 \mathrm{~N}, 15^{\circ} 46.317 \mathrm{E}, 1560 \mathrm{~m}$ a.s.l., 15.05.2015; P.110.2.1-109.2.2 slide No. 2118-2119 two specimens in Kőszeg Mts (Günzer Mts), near to Reichnitz, Austria, mixed forest (Pinus silvestris, Picea abies, Quercus petraea, Fagus sylvatica), $47^{\circ} 19.453 \mathrm{~N}, 16^{\circ} 25.400 \mathrm{E}, 589 \mathrm{~m}$ a.s.l., 21.05.2014; P110.3.1-109.3.5 slides No. 2121-2123, 2157, 2159, five specimens in Kőszeg Mts near to Steirer Houses, Hungary, Quercus petraea woodland with some Fagus sylvatica $47^{\circ} 22.411 \mathrm{~N}, 16^{\circ} 30.016 \mathrm{E} 521 \mathrm{~m}$ a.s.1.

Etymology - Named after the region where this species is an inhabitant of the eastern margin of Alps.

Diagnosis - The new species can be recognized by the following combination of characters: (1) medium size (7-16 mm in vivo), segments 38-52; (2) maximum 5-6 chaetae per bundle; (3) clitellum girdle-shaped: hyalocytes and granulocytes arranged in transverse rows; (4) five preclitellar pairs of nephridia; (5) coelomo-mucocytes numerous, a-type (according to MöLleR 1971), lenticytes 7-12 $\mu \mathrm{m}$; (6) chylus cells mostly in XVI-XVII; (7) bursal slit $\mathrm{T}$ or Y-shaped; (8) seminal vesicle large; (9) subneural glands in XIII-XV; (10) 
sperm funnel cylindrical, approximately half as long as body diameter, collar narrower as funnel body, sperm 150-220 $\mu \mathrm{m}$ long, sperm heads 60-75 $\mu \mathrm{m}$ long (fixed); (11) spermatheca separate entally, with two sessile, sphaerical diverticula and a large ectal gland.

Description - Holotype in vivo $6.9 \mathrm{~mm}$ long, $350 \mu \mathrm{m}$ wide at VIII and $380 \mu \mathrm{m}$ at the clitellum (fixed), 51 segments. Body length of the paratypes 7-16 mm, width $300-400 \mu \mathrm{m}$ at VIII and 340-400 $\mu \mathrm{m}$ at the clitellum (in vivo). Length of fixed specimens $4.7-11 \mathrm{~mm}$,
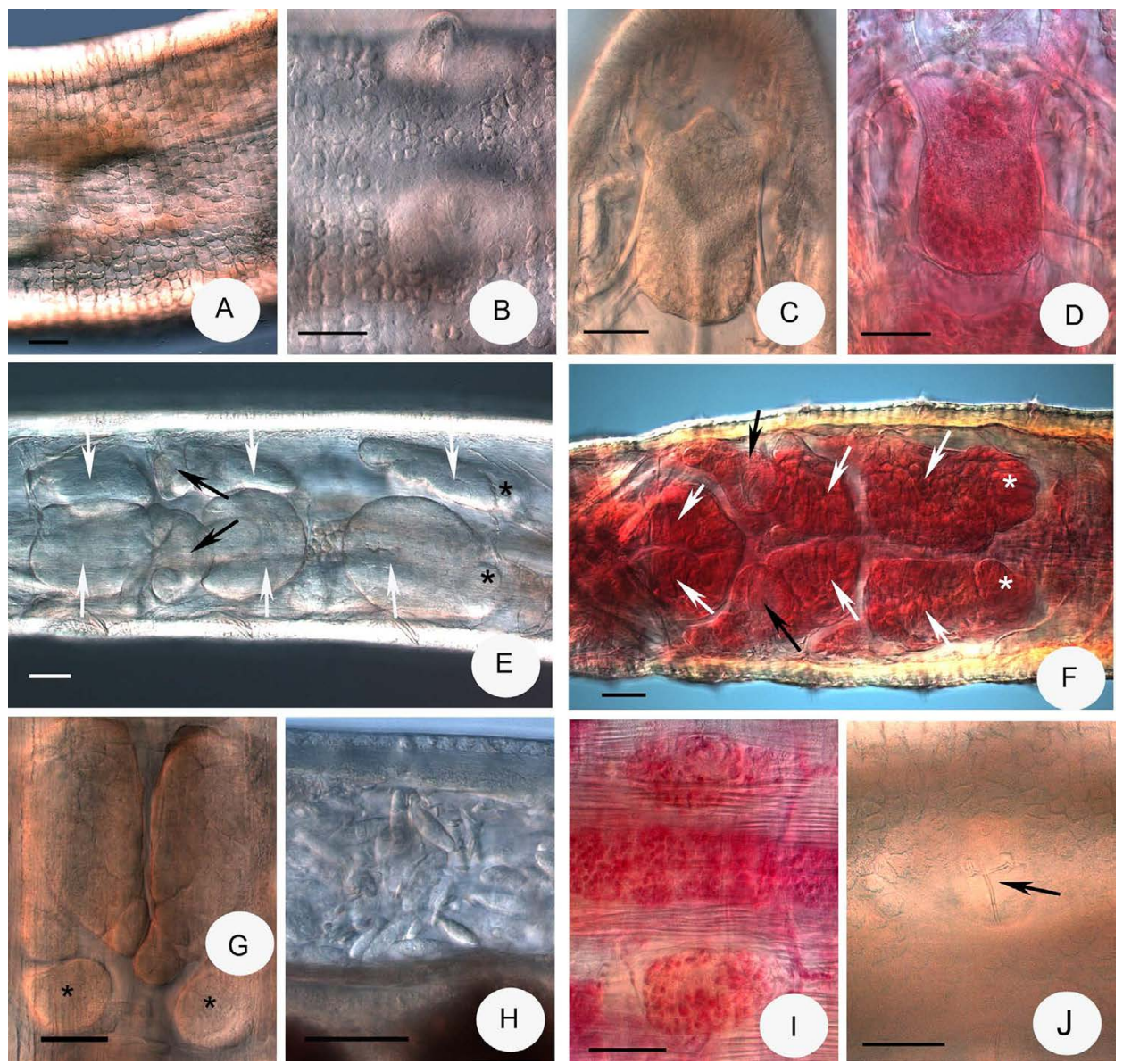

Fig. 1. Micrograph of Fridericia alpica sp. n. A = clitellar glands dorsally, $B=$ clitellar glands ventrally, $\mathrm{C}-\mathrm{D}=$ brain, $\mathrm{E}-\mathrm{F}=$ pharyngeal glands (marked with white arrows, ${ }^{*}=$ ventral projections, spermathecae marked with black arrows, $\mathrm{E}=$ dorso-lateral view, $\mathrm{F}=$ dorsal view), $\mathrm{G}=$ third pairs of pharyngeal glands, ventral view ( ${ }^{*}=$ ventral projections), $\mathrm{H}=$ coelomocytes, $\mathrm{I}=$ male copulatory organs, $\mathrm{J}=$ bursal slit (marked with arrow). (A-C, E, G-H, J in vivo, D, F, I fixed, stained; scale bars $=50 \mu \mathrm{m}$ ) 
width $270-380 \mu \mathrm{m}$ at VIII and 310-430 $\mu \mathrm{m}$ at the clitellum. Segments $38-52$. Chaetal formula: 2,(1),3,4,5 - 5,4,3,2: (1,2),3,4,5,6-6,5,4,3,2(1). As in other Fridericia species, chaetae in bundles arranged in pairs with the outer pair being longer and thicker than the inner pairs: $58-70$ by $5-6 \mu \mathrm{m}$ against $43-60$ by $4-5 \mu \mathrm{m}$ and $25-40$ by $3 \mu \mathrm{m}$ (preclitellar bundles), at body-end only 2 (1) chaetae per bundle, length about $65-75$ by $5-6 \mu \mathrm{m}$. Head pore at $0 / \mathrm{I}$. Dorsal pores from VII. Epidermal gland cells weakly developed. Clitellum in XII-1/2XIII, girdle-shaped, hyalocytes and granulocytes arranged in transverse rows dorsally (Fig. 1A), glands ventrally mostly weakly developed only (Fig. 1B). Thickness of body wall about 30-60 $\mu \mathrm{m}$, cuticle about $1-1.5 \mu \mathrm{m}$ in vivo. Brain egg-shaped, about $140-160 \mu \mathrm{m}$ long, 2 times longer than wide in vivo (Fig. 1C) and 120-140 $\mu \mathrm{m}$ and 1.5 times longer than wide in the fixed specimens (Fig. 1D).

Oesophageal appendages, long, without branches. Pharyngeal glands in $4 / 5$ united dorsally, with small ventral lobes, in 5/6 united dorsally or free with medium large ventral lobes, in 6/7 free dorsally with large ventral lobes and ventral projections (Figs. 1E-G). Chloragocytes from V, brown in vivo. Dorsal vessel from XVI-XXI, blood colourless. Midgut pars tumida in XXVII-XXXIII occupying 5-6 segments (Fig. 2A). Five pairs of preclitellar nephridia from $6 / 7$ to $10 / 11$, length ratio anteseptale : postseptale 1:1.5-2, midventral origin of efferent duct. Coelomo-mucocytes numerous, a-type (according to MöLler 1971) (length 29-42 $\mu \mathrm{m}$ in vivo, (10-20 $\mu \mathrm{m}$ fixed), lenticytes, 6-10 $\mu \mathrm{m}$ long (Fig. 1H). Chylus cells between XVI-XVII, occupying 2 segments. Seminal vesicle large. Sperm funnels cylindrical (Figs 2C, D), about 150-280 $\mu \mathrm{m}$ long and 2-3 times as long as wide (in vivo). Funnel length in fixed specimens 140-180 $\mu \mathrm{m}$. Collar not narrower than funnel body. Spermatozoa about 200-300 $\mu \mathrm{m}$ long, heads 70-150 $\mu \mathrm{m}$ in vivo, in fixed specimens 150-220 $\mu \mathrm{m}$ and 60-75 $\mu \mathrm{m}$, respectively. Diameter of sperm ducts $9-10 \mu \mathrm{m}$ (in vivo). Male copulatory organs (Fig. 1I) small 100-150 $\mu \mathrm{m}$ long, 55-75 $\mu \mathrm{m}$ wide and 45-55 $\mu \mathrm{m}$ high (in vivo), (80-120, 50-70 and $40-45 \mu \mathrm{m}$ in fixed specimens, respectively). Bursal slits T- or Y-shaped (Fig. 1J). Subneural glands in XIII-XV, the first are the largest (Fig. 2B). Spermathecae (Figs 2E-F): one 45-50 $\mu \mathrm{m}$ long (in vivo) stalked ectal gland at the orifice (Fig. 2F), 35-57 $\mu \mathrm{m}$, fixed. Ectal ducts

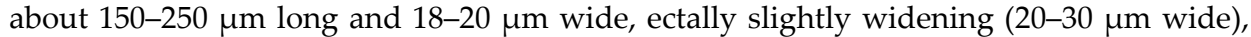
projecting into ampullae, ental bulbs about 40-60 $\mu \mathrm{m}$ wide, canals not widened. Each ampulla with two rounded, mostly sessile diverticula, located on opposite sides at the ampulla. The diameter of the diverticula $45-60 \mu \mathrm{m}$, ampullae $60-80 \mu \mathrm{m}$ wide, proximal part of ampulla considerably set off from distal part by a constriction, 45-50 $\mu \mathrm{m}$ long (fixed); separate openings into oesophagus. 2-3 mature eggs at a time.

Distribution and habitat - Austria: Rax Mountain in the habitats of mountain meadow and Pinus mugo and Picea abies stands, further Köszeg Mts (Günser Mts) in mixed forest. Hungary: Köszeg Mts near to Steirer Hauses, in Quercus petraea woodland with some Fagus sylvatica. The species lives presumably in the Alps and their foothills in the Western geographic region of Hungary.

Remarks - The new species can be well distinguished from all Fridericia species having two sessile spermathecal divericula and non-fused ampullae (see the Tables 3-4 in Dózsa-Farkas 2009 and Dózsa-Farkas et al. 2015), except $F$. discifera. The differential diagnosis from this species is given below.

Comparison of F. alpica sp. n. and Fridericia discifera Healy, 1975 - The two species are very similar, so for their proper discrimination we have combined morphological and molecular methods. Previously Schmelz (2003) also 
indicated that some specimens found in the Alps and identified as F. discifera could belong to a yet undescribed Fridericia species. We found that the two above-mentioned species occur together both in the Rax Mt. and also in the Köszeg Mts in Hungary, moreover F. alpica sp. n. was found in Hungary and also Austria (where this mountain range is called Günser Mountains).

We made a comparison on the basis of the descriptions of $F$. discifera by Healy (1975) and Schmelz (1999) as well as based on specimens collected in this study. Many traits of the two species are very similar, the morphological comparison of the similar characters are given in Table 2. Dissimilar charac-
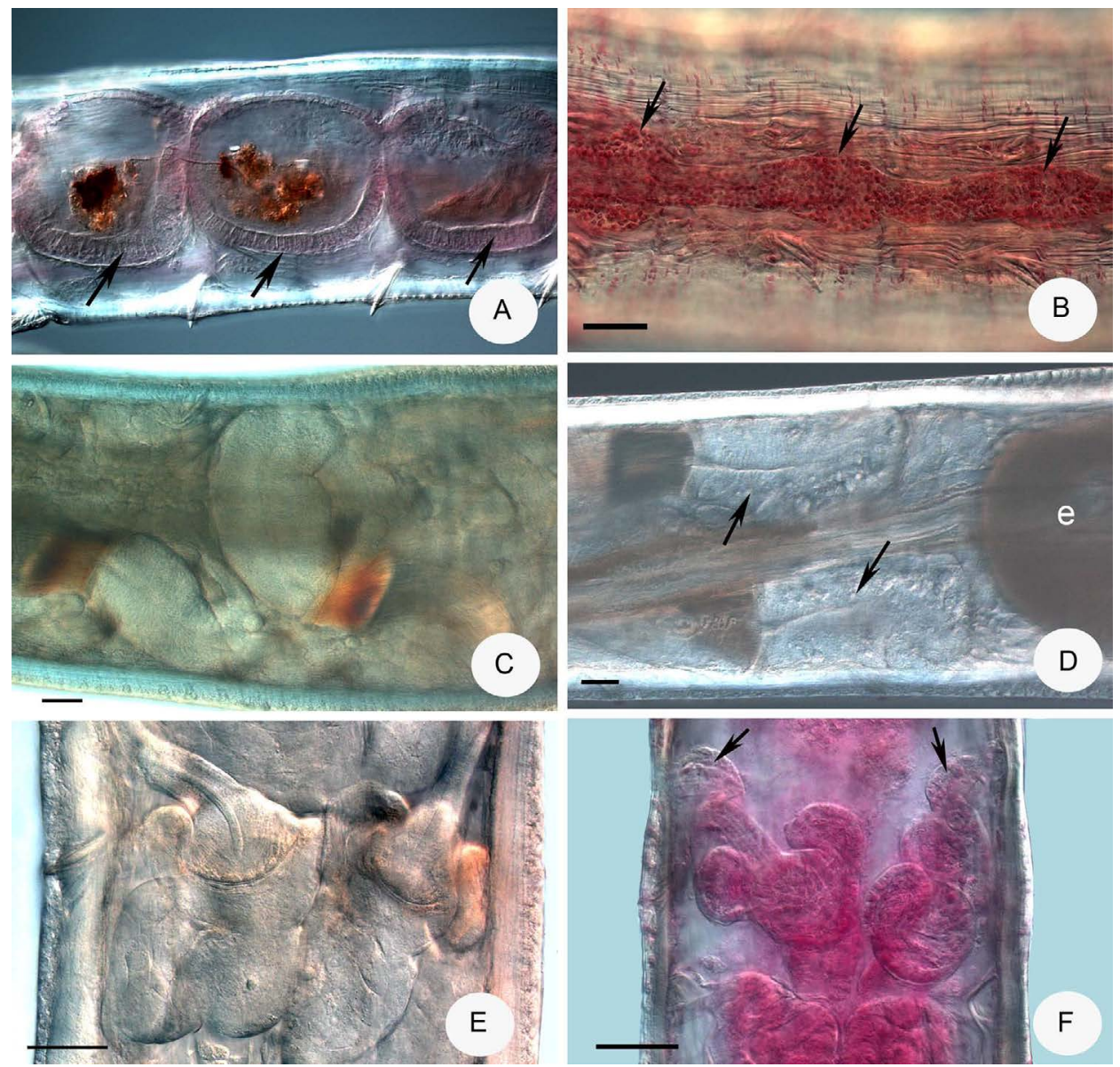

Fig. 2. Micrograph of Fridericia alpica sp. n. $A=$ midgut pars tumida in XXX-XXXI, lateral view (marked with arrows), B = subneural glands in XIII-XV (marked with arrows), C-D sperm funnels (in D marked with arrows, e = egg), E-F spermathecae (in $\mathrm{F}$ the large ectal

glands marked with arrows). (A-B, F fixed, stained, C-E in vivo, scale bars $=50 \mu \mathrm{m}$ ) 
Table 2. Morphological comparison of F. discifera and F. alpica sp. n. Only similar traits are shown (in vivo values are bold, other values measured as fixed).

\begin{tabular}{|c|c|c|}
\hline & F. discifera & F. alpica sp. $n$. \\
\hline number of segments & $38-49$ & $38-52$ \\
\hline length (mm) & $\begin{array}{l}\mathbf{8 . 5}-\mathbf{1 2} \\
7.5-10\end{array}$ & $\begin{array}{c}7-16 \\
4.7-11\end{array}$ \\
\hline diameter in VIII $(\mu \mathrm{m})$ & $\begin{array}{l}250-320 \\
270-380\end{array}$ & $\begin{array}{l}300-400 \\
270-380\end{array}$ \\
\hline diameter in XII $(\mu \mathrm{m})$ & $\begin{array}{l}280-370 \\
290-400\end{array}$ & $\begin{array}{l}340-400 \\
310-430\end{array}$ \\
\hline type of oesophagus appendages & a & a \\
\hline dorsal vessel & XVI-XXII & XVI-XXI \\
\hline chylus cells (occupying segments) & XIV-XVII (2) & XVI-XVII (2) \\
\hline length of brain (mm) (length:diameter) & $\begin{array}{l}\text { 140-160 } \\
(2: 1)\end{array}$ & $\begin{array}{l}\text { 140-160 } \\
(2: 1)\end{array}$ \\
\hline $\begin{array}{l}\text { length of sperm funnel (mm) } \\
\text { (length:diameter) }\end{array}$ & $\begin{array}{c}\text { 150-250 (2-3) } \\
80-180 \\
(1.5-2.2: 1)\end{array}$ & $\begin{array}{c}\text { 150-280 (2-3) } \\
140-180 \\
(1.5-2: 1)\end{array}$ \\
\hline length of spermatozoa $(\mu \mathrm{m})$ & $\begin{array}{c}250-300 \\
110\end{array}$ & $\begin{array}{l}200-300 \\
150-220\end{array}$ \\
\hline length of sperm head $(\mu \mathrm{m})$ & $\begin{array}{c}\mathbf{1 0 0}-\mathbf{1 2 0} \\
58-65\end{array}$ & $\begin{array}{c}70-150 \\
60-75\end{array}$ \\
\hline small male copulatory organ $(\mu \mathrm{m})$ & $\begin{array}{c}85-140 \\
70-90\end{array}$ & $\begin{array}{c}100-150 \\
80-20\end{array}$ \\
\hline bursal slits & T or Y-shaped & T or Y-shaped \\
\hline
\end{tabular}

ters are listed here. The maximum number of chaetae in a bundle is only 4 in $F$. discifera, but 5 or 6 in F. alpica. The body wall in both species has approximately the same width (in our F. discifera $30-40 \mu \mathrm{m}$, according to ScHmelz (1999) only 20-25 $\mu \mathrm{m}$, in F. alpica the same or slightly thicker: 30-60 $\mu \mathrm{m}$ ), but the cuticle is in F. discifera much thicker, i.e. 5-9 $\mu \mathrm{m}$ (Fig. 3D) than in F. alpica, where it has only 1-1.5 $\mu \mathrm{m}$ (fixed). There are only 4 pairs of preclitellar nephridia in F. discifera, but 5 pairs in the new species. The mucocytes are very scarce and with hyaline matrix and small refractile vesicles at periphery in F. discifera (Fig. 3F) but numerous and of a-type (without refractile vesicle) in F. alpica (Fig. 1H). Lenticytes are of about the same length in both species. The pharyngeal glands are also slightly different: in F. alpica the first pair is connected dorsally and has small ventral lobes, the second pair is connected dorsally or free and has medium large ventral lobes, and the third pair is free dorsally, has large ventral lobes and projections backwards (Figs 2E-G). In F. discifera, the first pair of pharyngeal glands is of the same kind, the secondary 
pair is also similar, but always connected dorsally, the third pair is also similar, but the projection absent (Fig. 3E). Both species have subneural glands, but in F. alpica in XIII-XV (in 3 segments) (Fig. 2B), whereas in F. discifera only in XIII-XIV (in 2 segments). The spermathecae are very similar (Figs 2E-F and 3I) either, except the ectal gland, which is larger (35-57 $\mu \mathrm{m}$ long, fixed) and stalked in F. alpica (Fig. 2F) but only 17-25 $\mu \mathrm{m}$ long and sessile in F. discifera (Fig. 3I).
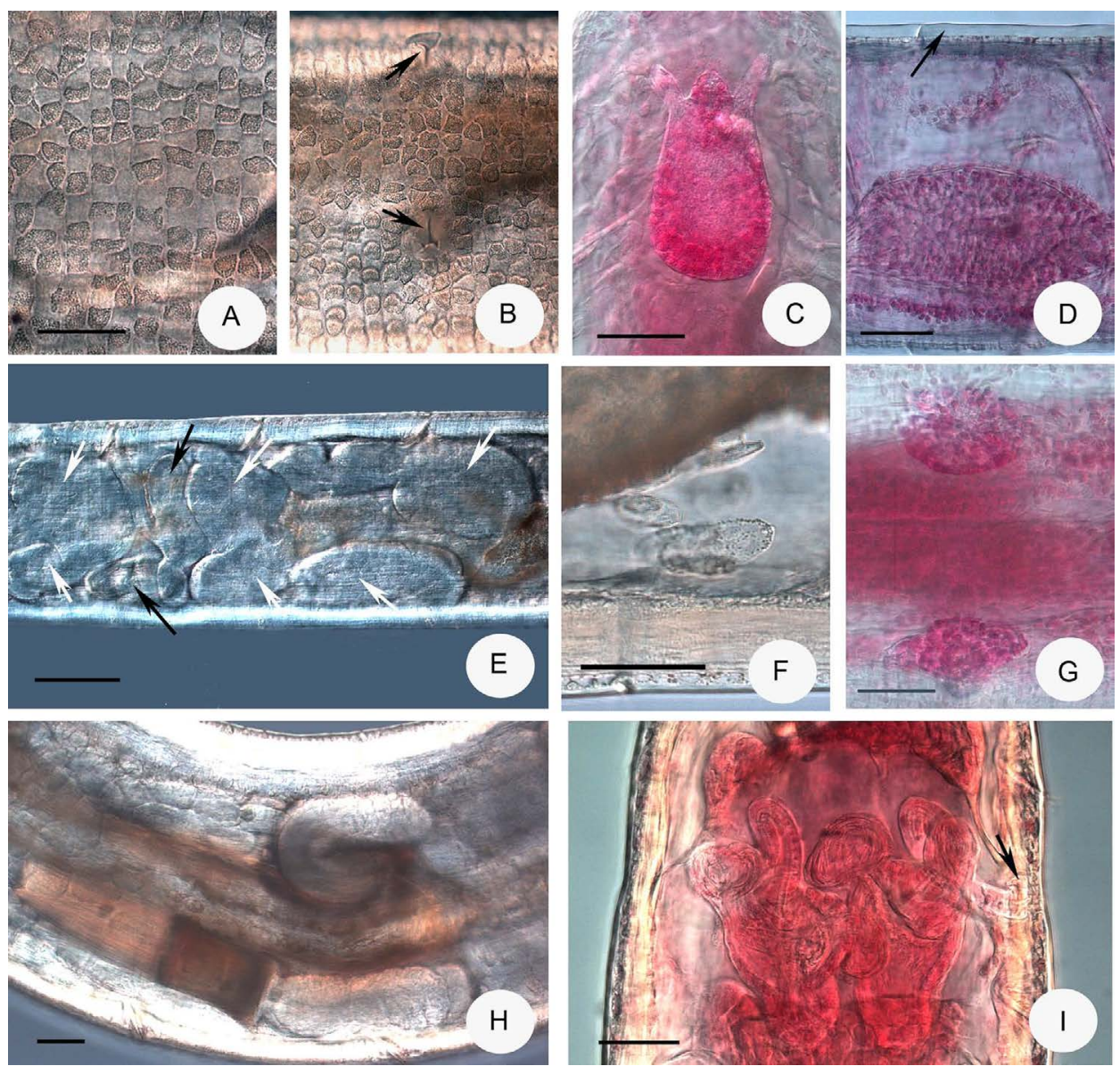

Fig. 3. Micrograph of Fridericia discifera. $\mathrm{A}=$ clitellar glands dorsally, $\mathrm{B}=$ clitellar glands ventrally (bursal slits marked with arrows), $C=$ brain, $D=$ body wall, thick cuticle (marked with arrow), $\mathrm{E}=$ pharyngeal glands dorsal view (marked with white arrows, no ventral projections, spermathaecae marked with black arrows), $\mathrm{F}=$ coelomocytes, scarce, a/btype, $\mathrm{G}=$ male copulatory organs, $\mathrm{H}$ = sperm funnels, $\mathrm{I}=$ spermathaecae (small ectal gland marked with arrow). (A-B, E-F, H in vivo, C-D, G, I fixed, stained; scale bars $=50 \mu \mathrm{m}$ ) 
Fridericia cf. discifera described by Rота (1995) from Tuscany and Umbria, Italy, differs considerably from $F$. discifera proper, therefore Schmelz (1999) had the opinion that this is another, yet undescribed species. However, it also differs from F. alpica sp. n. The main differences are as follows: the oesophageal appendages are branched whereas unbrached in F. alpica, the coelomocytes according to Figure 9C (RоTA 1995) are c-type (according to MöLLER 1971) and larger (maximum of $55 \mu \mathrm{m}$, whereas a-type and only $29-42 \mu \mathrm{m}$ long in the new species). The spermathecal ectal ducts are much longer $520-550 \mu \mathrm{m}$, whereas only $150-250 \mu \mathrm{m}$ in F. alpica.

\section{Fridericia raxiensis $\mathrm{sp} . \mathrm{n}$.}

(Figs 4-5)

Type material - Holotype. F.27. slide No. 2125, Rax Mountain, close to the Rax cable car terminal, under Pinus mugo $47^{\circ} 43.036 \mathrm{~N}, 15^{\circ} 46.024 \mathrm{E}, 1620 \mathrm{~m}$ a.s.l., leg. Farkas, J., 15.05.2012.

Paratypes. In total 12 specimens P.111.1.1.-111.1.4. slide No. 2229-2233 four specimens Rax Mountain, close to the Rax cable car terminal, under Pinus mugo, $47^{\circ} 43.23 .3 \mathrm{~N}$, 1545.164E $1612 \mathrm{~m}$ a.s.l., leg. Farkas, J., 15.05.2012; P.111.2.1-111.2.3 slide No. 2126-2128 three specimens Rax Mountain, close to the Rax cable car terminal, subalpine meadow, 47 $43.172 \mathrm{~N}, 15^{\circ} 45.218 \mathrm{E}, 1613 \mathrm{~m}$ a.s.l., leg. Farkas, J., 15.05.2012; P.111.3.1-111.3.2 slide No. 2227-2228 two specimens Rax Mountain, close to the Rax cable car terminal, under Pinus mugo $47^{\circ} 43.007 \mathrm{~N}, 15^{\circ} 45.401 \mathrm{E}, 1613$ m a.s.l., leg. Farkas, J., 15.05.2015; P.111.4.1-111.4.3 slide No. 2239-2241 three specimens Rax Mt. 4771.666N, 1577.305E, 1613 m a.s.l., under Pinus mugo leg. Bauer, R., 10.06.2008.

Etymology - Named after the Rax Mountain where this species was found.

Diagnosis - The new species can be recognized by the following combination of characters: (1) medium size (14-18 mm in vivo), segments 51-59; (2) maximum 5 chaetae per bundle; (3) clitellum girdle-shaped: hyalocytes and granulocytes arranged in transverse rows but weakly developed; (4) five preclitellar pairs of nephridia; (5) coelomo-mucocytes numerous, c/b-type (according to Möller 1971), scarce, 30-44 $\mu \mathrm{m}$ in vivo, lenticytes $8-10 \mu \mathrm{m}$ long; (6) chylus cells in XIII-XVI (3-4 segments long); (7) bursal slit T-shaped, the transverse component is short; (8) seminal vesicle large; (9) a small subneural gland in XIII; (10) sperm funnel pear-shaped, approximately half as long as body diameter, collar narrower as funnel body, sperm 340-370 $\mu \mathrm{m}$ long, heads 75-85 $\mu \mathrm{m}$ in vivo; (11) spermatheca with long ectal duct, large ectal gland, ampulla entally separate, with about 8 sessile, sphaerical diverticula varying in size.

Description - Holotype $11.7 \mathrm{~mm}$ long, $380 \mu \mathrm{m}$ wide at VIII and $380 \mu \mathrm{m}$ at the clitellum (fixed), 51 segments. Body length of the paratypes $14-18 \mathrm{~mm}$, width $350-410 \mu \mathrm{m}$ at 
VIII and 370-480 $\mu \mathrm{m}$ at the clitellum (in vivo). Length of fixed specimens $8-13 \mathrm{~mm}$, width $350-440 \mu \mathrm{m}$ at VIII and 380-470 $\mu \mathrm{m}$ at the clitellum. Segments 51-59. Chaetal formula: $2,3,4-4,3,2,(1): 3,4,5-4,3,2$. Chaetae in bundles arranged in pairs with the outer pair being longer and thicker than the inner pair: $45-60$ by $5 \mu \mathrm{m}$ against $35-40$ by $2.5-3 \mu \mathrm{m}$. Chaetal lengths about the same also in postclitellar segments. From about XXX only two chaetae per bundle, but in one case (slide No. 2229) already from XXV, these about $60 \mu \mathrm{m}$ long and $5 \mu \mathrm{m}$ wide in terminal segments. Head pore at 0/I. Dorsal pores from VII. Epidermal gland cells in 5-9 transverse rows per segment (Fig. 4A). Body wall thick, about $50 \mu \mathrm{m}$, the cuticle 3-5 $\mu \mathrm{m}$, so that internal organs are often difficult to investigate in vivo. Clitellum in XII-1/2XIII, girdle-shaped, glands arranged in transverse rows, weakly developed (Fig. 4B).

Brain egg-shaped, about 140-160 $\mu \mathrm{m}$ long, 2 times longer than wide in vivo and 120$160 \mu \mathrm{m}$ and 1.5 times longer than wide in the fixed specimens (Fig.4C). Oesophageal appendages extending into $\mathrm{V}$, without branches. Pharyngeal glands are very characteristic. All pairs connected dorsally (sometimes the third is free), ventral lobes absent in IV. Large additional ventral lobes in segment VII (Fig. 4G). Chloragocytes from V, brown in vivo. Dorsal vessel from XVII-XX, blood colourless. Midgut pars tumida not visible. Five pairs of preclitellar nephridia from 6/7 to 10/11 (Fig. 4D), large anteseptale, the length ratio anteseptale : postseptale 1:1.2-1.6, posteroventral origin of efferent duct. Coelomo-mucocytes oval, numerous, c/b-type, matrix fine granulous with some refractile grains, length 30-44 $\mu \mathrm{m}$ in vivo (Fig. 4E), but in the fixed specimens the matrix of the mucocytes (24-36 $\mu \mathrm{m}$ long) considerably granulous with well stained nucleus (Fig. 4F). Lenticytes scarce, 8-10 $\mu \mathrm{m}$ long. Chylus cells (Fig. 4H) between XIII-XVI, occupying 3-4 segments. Seminal vesicle large, in X-XI. Sperm funnels nearly pear-shaped, about 170-250 $\mu \mathrm{m}$ long and 1.5-2 times as long as wide (in vivo) (Fig. 5A). Funnel length in fixed specimens 120-190 $\mu \mathrm{m}$ and about 1.4 times longer than wide (Fig. 5B). Collar narrower than the funnel. Spermatozoa about 340-370 $\mu \mathrm{m}$ long, heads 75-85 $\mu \mathrm{m}$ in vivo, in fixed specimens $250-300 \mu \mathrm{m}$ and $45-60 \mu \mathrm{m}$, respectively. Diameter of sperm ducts $6-8 \mu \mathrm{m}$ (fixed). Male copulatory organs (Figs $4 \mathrm{I}$, 5C) small, 140-160 $\mu \mathrm{m}$ long, 70-90 $\mu \mathrm{m}$ wide and $60 \mu \mathrm{m}$ high (in vivo), (100-120, 60-90 and 40-60 $\mu \mathrm{m}$ in fixed specimens, respectively). Bursal slits T-shaped, but the transverse component is short and the longitudinal component at the two ends with two short transverse components too (Fig. 5C). One small subneural gland in XIII (Fig. 4I). Spermathecae (Figs 5D-F): one large, 40-60 $\mu \mathrm{m}$ long (in vivo and fixed equally) ectal gland at the orifice (Figs 5E-F). Ectal ducts about 320-390 $\mu \mathrm{m}$ long and 18-20 $\mu \mathrm{m}$ wide $(250-330 \mu \mathrm{m}$ long and 16-18 $\mu \mathrm{m}$ wide, fixed), projecting into ampullae, ental bulbs about $40 \mu \mathrm{m}$ wide in vivo, canals not widened. About 6-9 sessile diverticula (mostly 8) of varying size: diameter (16)-30-50 $\mu \mathrm{m}$ (fixed). Sperm in a circle in lumen of ampullar distal part. Diameter of ampulla and diverticula together 90-120 $\mu \mathrm{m}$. The epithelium of diverticula in vivo thick and warty (Fig. 5D), mostly no sperm in the diverticula. Separate openings into oesophagus dorso-laterally. One or two mature eggs at a time.

Distribution and habitat - Only known from the type locality.

Differential diagnosis - The number of valid Fridericia species with more than two diverticula per spermatheca is 18: F. agilis Smith, 1895; F. agricola Moore, 1895; F. bernini Dózsa-Farkas, 1988; F. douglasensis Welch, 1914; F. dura Eisen, 1879; F. firma Smith et Welch, 1913; F. glandifera Friend, 1911; F. galba (Hoffmeister, 1843); F. gigantea Dequal, 1912; F. hegemon (Vejdovksy, 1878); F. minor Friend, 1913; F. oconeensis Welch, 1914; F. paraunisetosa Xie, Liang et 
Wang, 2000; F. pyrenaica Gianni, 1979; F. regularis Nielsen et Christensen, 1959; F. terrarossae Sesma et Dózsa-Farkas, 1993; F. vixdiverticulata Sesma et DózsaFarkas, 1993; F. callosa (Eisen, 1878) (type with diverticula).

The new species differs from all these species, leaving other characters out of consideration, by the presence of the additional large ventral lobes of pharyngeal glands in VII, which is a very rare character among the Fridericia species.
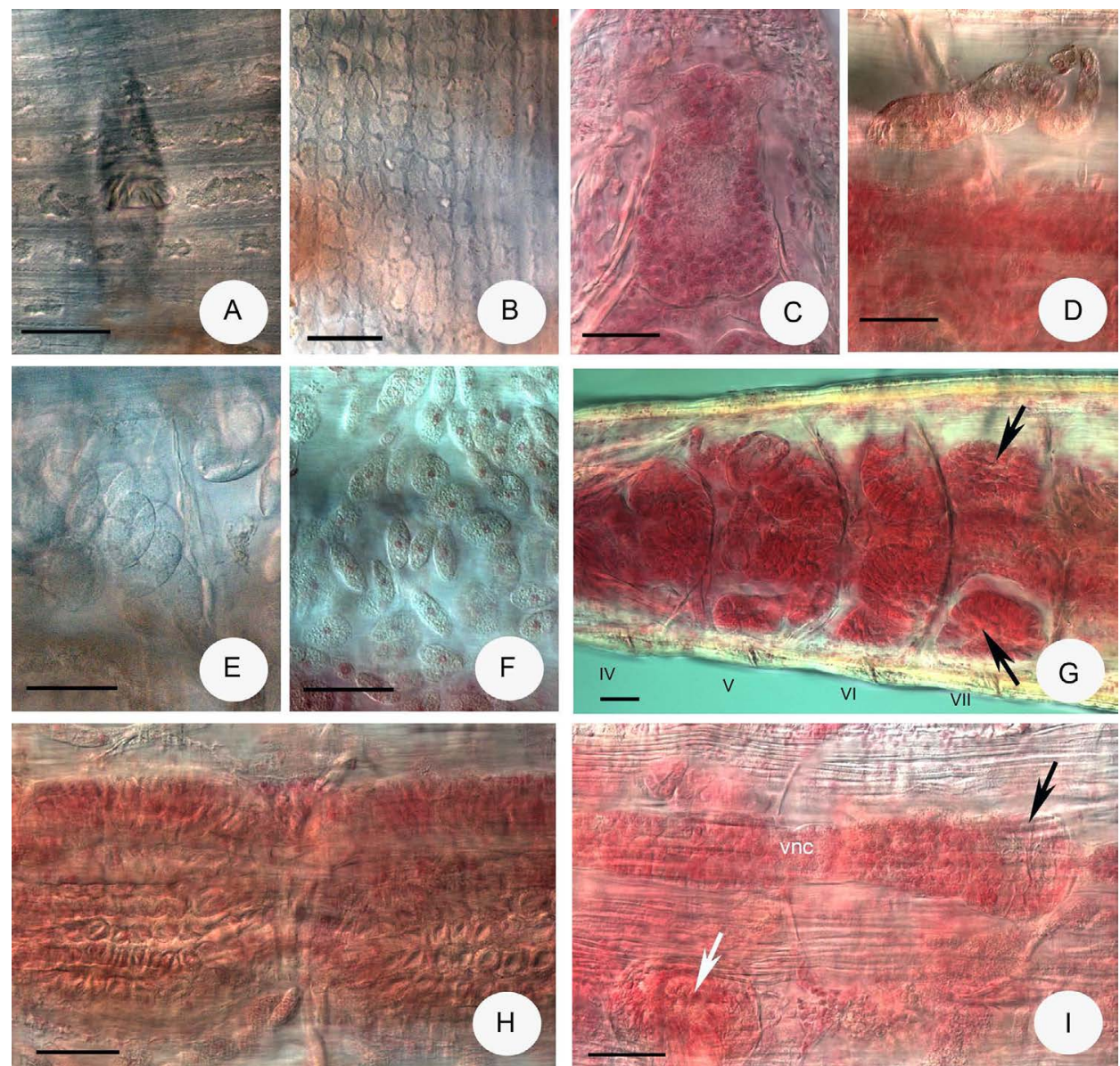

Fig. 4. Micrograph of Fridericia raxiensis sp. n. A = epidermal glands, $\mathrm{B}=$ clitellar glands dorsally (weakly developed), $\mathrm{C}=$ brain, $\mathrm{D}=$ second nephridium preclitellarly, $\mathrm{E}-\mathrm{F}=$ coelomocytes, $\mathrm{G}=$ pharyngeal glands dorsal view (the additional ventral lobes in VII marked with arrows), $\mathrm{H}=$ chylus cells in XIV-XV of holotype, $\mathrm{I}=$ male copulatory organ (marked with white arrow) and the small subneural gland in XIII (marked with black arrow). (A-B, E in vivo, C-D, F-I fixed, stained; scale bars $=50 \mu \mathrm{m}$ ) 


\section{Molecular results}

In total, 8, 10 and 12 sequences were obtained from various Fridericia specimens in the case of ITS, CO1 and H3, respectively, and some additional sequences obtained previously were also used for comparison (Table 3). Results of this molecular analysis confirmed that F. discifera and F. alpica sp. n. are distinct species, since they separated on the phylogenetic trees constructed based on the three studied regions (Fig. 6). Additionally, the other novel species, Fridericia raxiensis sp. n. also had a position on the trees distinct from any other similar species.

\section{DISCUSSION}

The enchytraeid fauna (41 species of 12 genera) of the Rax Mountain area is quite diverse, and consists mostly of species typical for the Northern and Central European fauna. An essential element of this fauna is Euenchytraeus clarae (BAUER, 1993), a typical species of the forest fauna of European mountains (Bretscher 1906, Bauer 1993, Schmelz \& Collado 2010), so it is understandable, that this species was found only in the Pinus mugo and Picea abies zone.
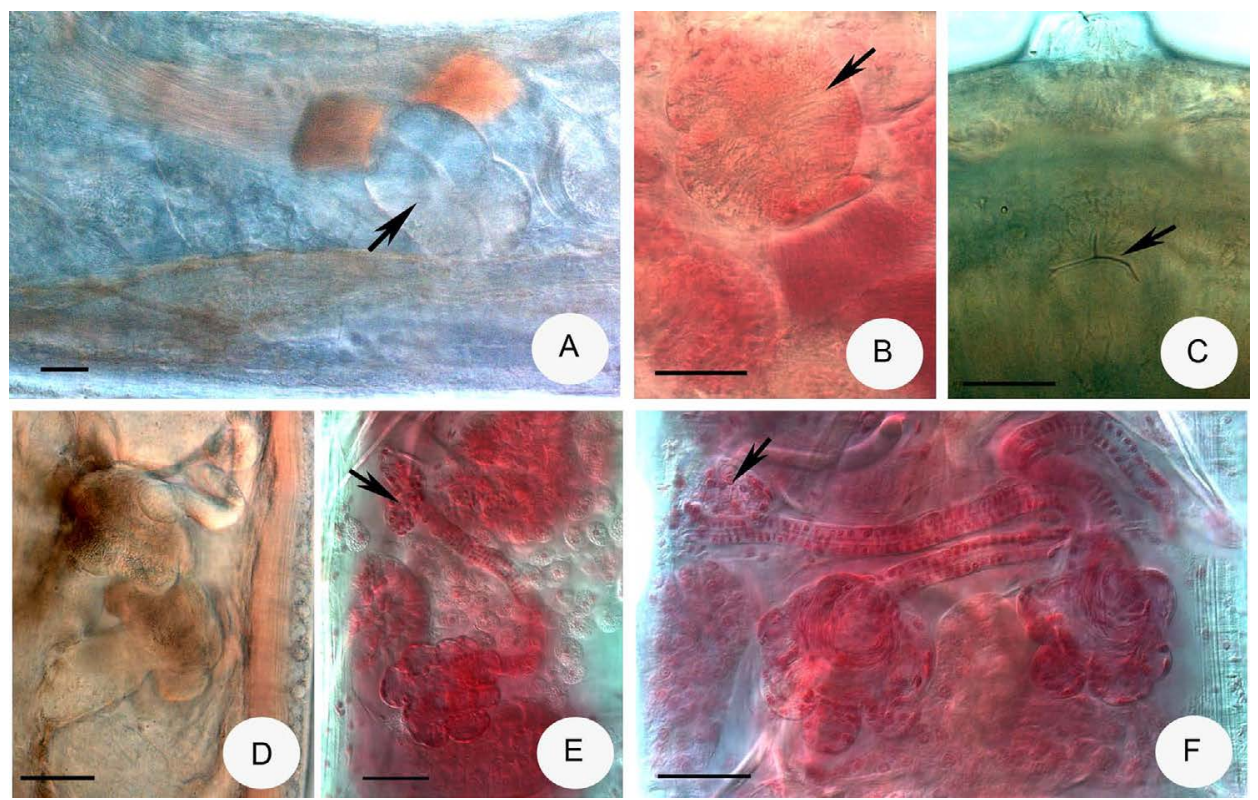

Fig. 5. Micrograph of Fridericia raxiensis sp. n. A-B = sperm funnels (marked with arrows), $\mathrm{C}=$ bursal slit (marked with arrow), D-F spermathecae (in $\mathrm{E}$ and $\mathrm{F}$ the large ectal glands marked with arrows). (A, C, D in vivo, B, E-F fixed, stained; scale bars $=50 \mu \mathrm{m}$ ) 


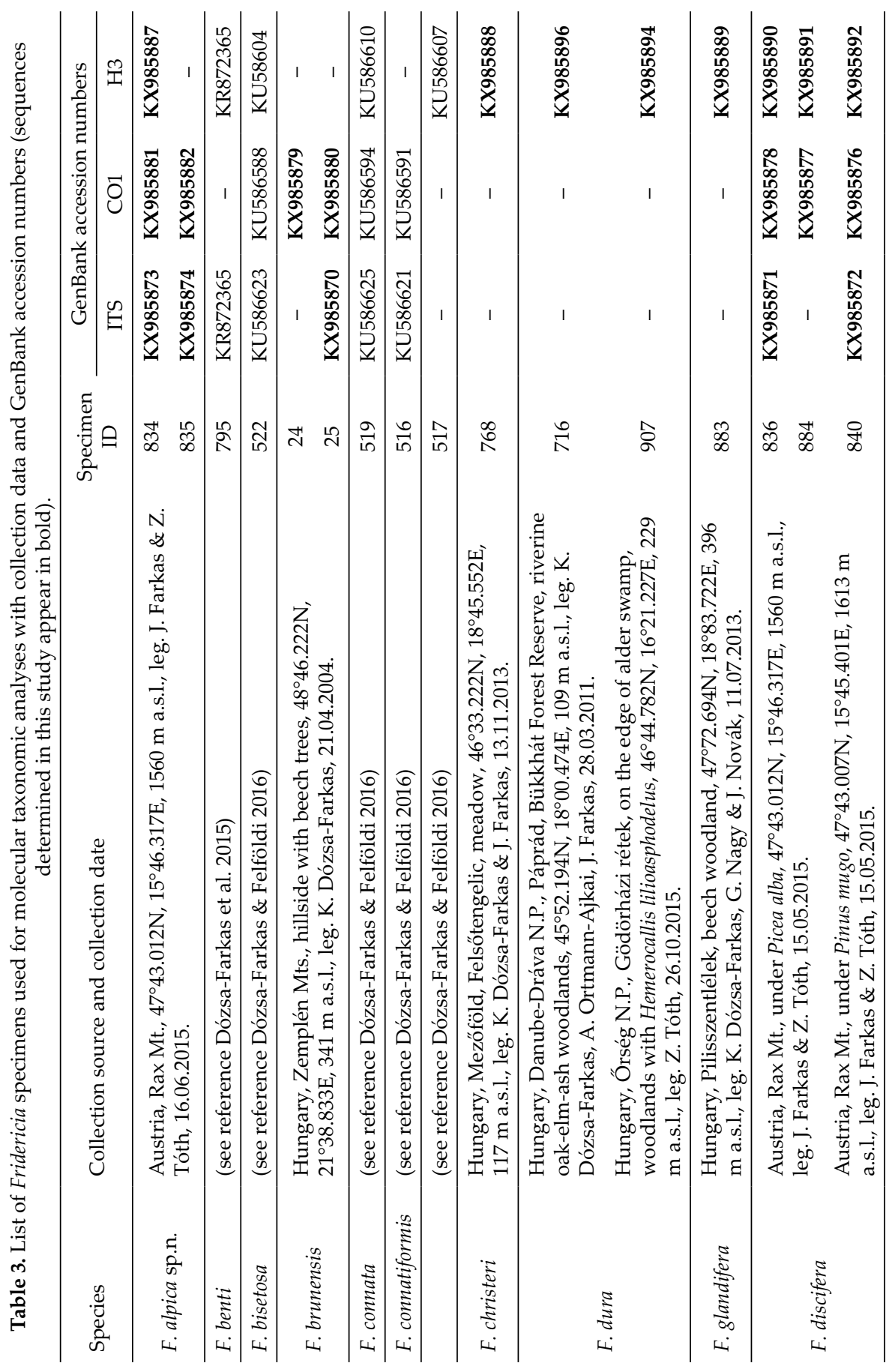




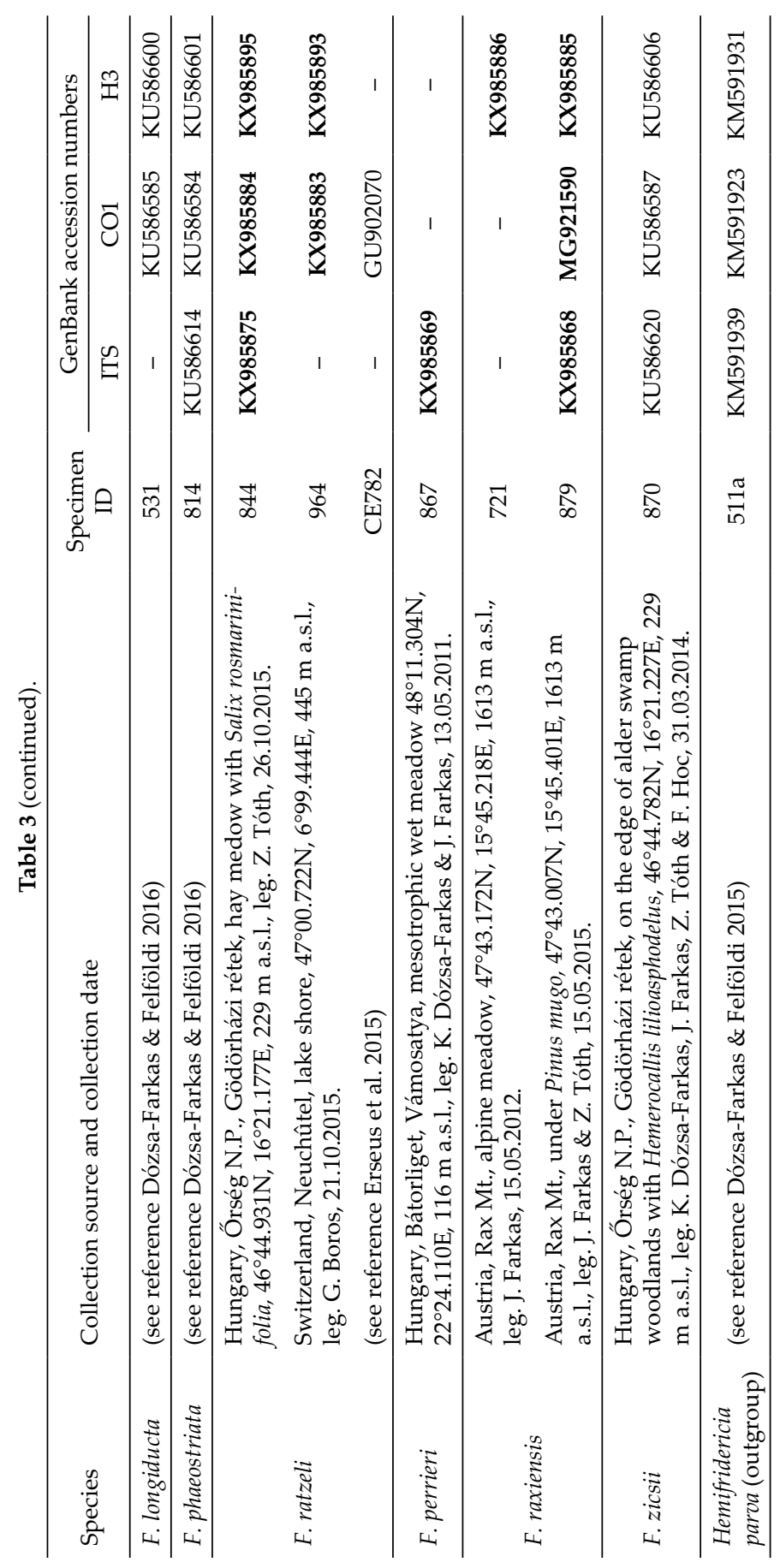




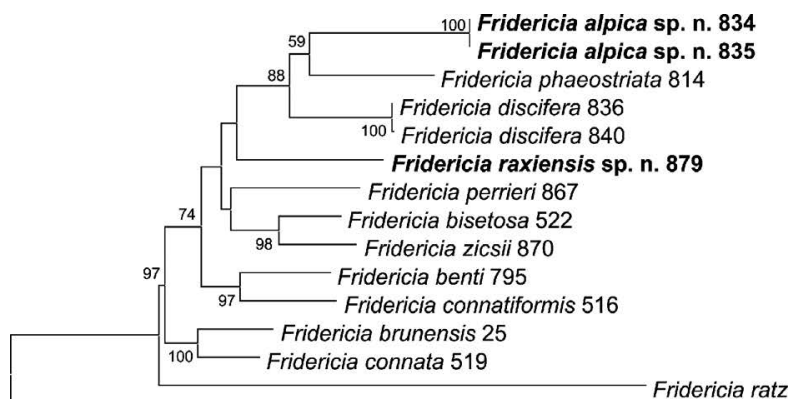

100 Fridericia alpica sp. n. 834
Fridericia alpica sp. n. 835

Fridericia discifera 840

Fridericia raxiensis sp. n. 879

Hemifridericia parva 511 a

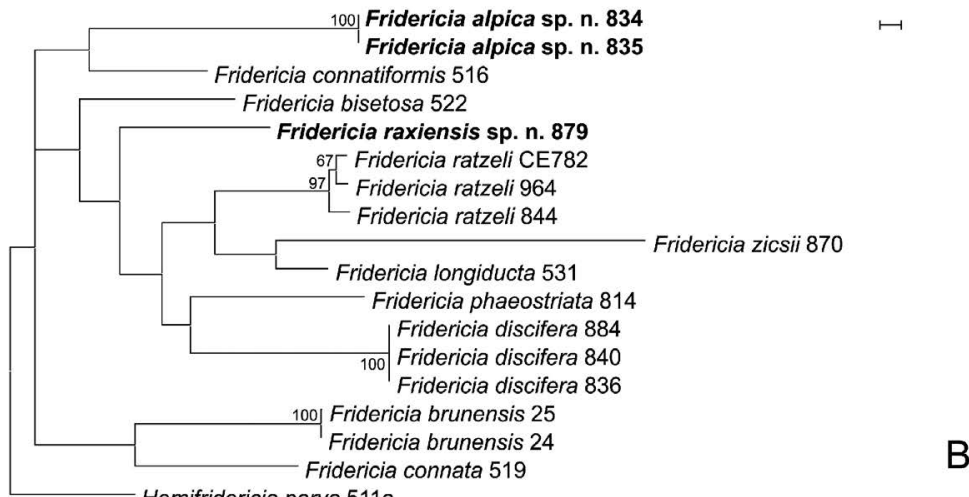

B

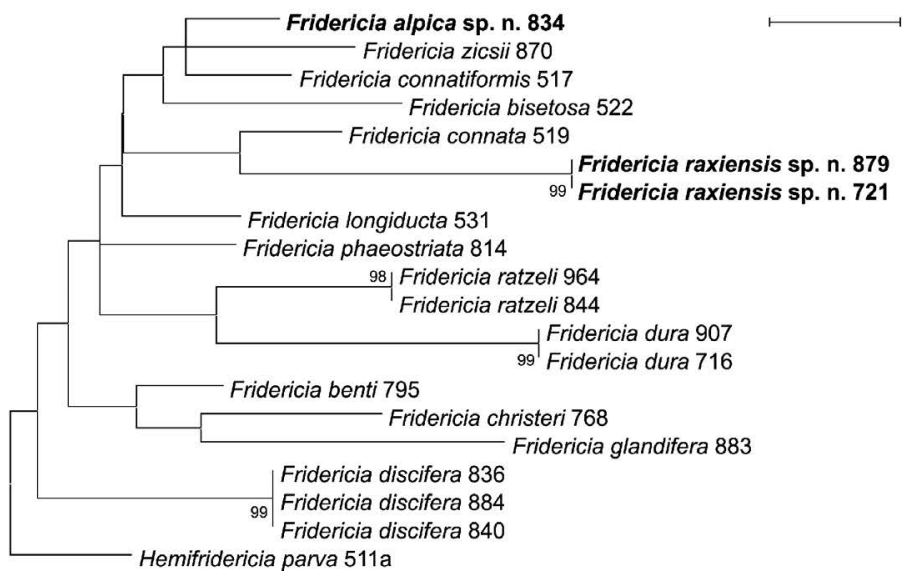

C

Fig. 6. Maximum likelihood (ML) trees of studied Fridericia species based on the ITS region (A), $\mathrm{CO} 1$ (B) and H3 genes (C). Bootstrap values greater than 50 are shown at the nodes. Sequences from new species described here appear in bold. A $=$ ML tree of the ITS region based on 779 nucleotide positions using the GTR $+\mathrm{G}+\mathrm{I}$ substitution model, B $=$ ML tree of the $\mathrm{CO} 1$ gene based on 423 nucleotide positions using the GTR+I substitution model, $\mathrm{C}=$ ML tree of the $\mathrm{H} 3$ gene based on 176 nucleotide positions using the K2+G substitution model. Scale bars, 0.05 substitutions per nucleotide position 
Regarding the species numbers of the investigated areas (Table 1 ), the fauna of Pinus mugo stands showed the highest value with 26 species (although it should be noted, that most samples were taken from this habitat). The habitat with Larix decidua showed low species richness with only 6 species present.

Using morphological characters, the two new species, F. alpica sp. n. and F. raxiensis sp. n. could easily be discriminated from other similar Fridericia species, and are well supported by the molecular results as well. Both new Fridericia species were found only in the highest region. F. raxiensis $\mathrm{sp}$. n. seems to be a species with a narrower geographical distribution, but the other new species, Fridericia alpica sp. n., occupies a broader area, as it was found also in Rax Mt. and in Köszeg Mountains (in Austria and Hungary), having an alpine or subalpine mesoclimate. Two presumably new species, Fridericia sp. and Enchytraeus sp., and the two species belonging to the Fridericia aurita species complex require further study before their descriptions can be published.

*

Acknowledgements - Many thanks to Dr. János Farkas and Dr. Zoltán Tóth for their assistance with the sampling and Dr. Roswitha Bauer for the enchytraeid specimens collected by her. The authors are also thankful to Bianka Csitári and Hajnalka Nagy for their technical assistance. Thanks for the anonymous referees contributed with their critical comments to the final version of the present study. This research was financed by the National Research, Development and Innovation Office (108582 NKFIH). Tamás Felföldi was supported by the New National Excellence Program of the Ministry of Human Capacities, Hungary (grant number: ÚNKP-17-4-III-ELTE-111).

\section{REFERENCES}

BAuer, R. (1993): Cognettia clarae n. sp. - eine neue Enchytraeiden-Art aus dem österreichischen Fichtenwald (Oligochaeta, Enchytraeidae). - Linzer biologische Beiträge 25: 685-689.

Bauer, R., Kampichler, C., Bruckner, A. \& Kandeler, E. (1994): Enchytraeids (Oligochaeta) in an Austrian spruce forest: abundance, biomass, vertical distribution and re-immigration into defaunated mesocosms. - European Journal of Soil Biology 30: 143-148.

BAuer, R. (1996a): Die Enchytraeidenfauna (Annelida; Oligochaeta) entlang eines Höhengradienten im Gasteiner Tal (Salzburg) und Beschreibung der neuen Art Fridericia antensteineri sp. n. - Linzer biologische Beiträge 28(1): 211-220.

BAUER, R. (1996b): On the distribution of enchytraeids and their bioindicative applicability. - Newsletter on Enchytraeidae 5: 11-16.

BAuer, R. (1998): Fridericia christiani sp. n. - a new enchytraeid species from a pasture in Salzburg (Austria). - Linzer biologische Beiträge 30(1): 5-9.

Bauer, R. (2002a): Comparison of the enchytraeid communities (Oligochaeta) in an Arctic and sub alpine area. - Natura Jutlandica, Occasional Papers 2: 25-31. 
BAuER, R. (2002b): Survival of frost and drought conditions in the soil by enchytraeids (Annelida; Oligochaeta) in Arctic, subalpine and temperate areas. - European Journal of Soil Biology 38: 251-254. https://doi.org/10.1016/S1164-5563(02)01154-8

BRETSChER, K. (1906): Über ein neues Enchytraeidengenus. - Zoologischer Anzeiger 29: 627-674.

Colgan, D. J., Mclauchlan, A. A., Wilson, G. D. F., Livingston, S. P., Edgecombe, G. D., Macaranas, J., Cassis, G. \& Gray, M. R. (1998): Histone H3 and U2 snRNA DNA sequences and arthropod molecular evolution. - Australian Journal of Zoology 46: 419_ 437. https://doi.org/10.1071/ZO98048

Dózsa-FARKAs, K. (1973): Ananeosis, a new phenemenon in the life-history of Enchytraeidae. - Opuscula Zoologica, Budapest 12 (1-2): 43-55.

Dózsa-Farkas, K. (2009): Review of the Fridericia species (Oligochaeta: Enchytraeidae) possessing two spermathecal diverticula and description of a new species. - Journal of Natural History 43 (17-18): 1043-1065. https://doi.org/10.1080/00222930902767441

Dózsa-Farkas, K. \& Felföldi, T. (2015): Unexpected occurrence of Hemifridericia bivesiculata Christensen \& Dózsa-Farkas, 2006 in Hungary, a species presumed to be endemic to Devon Island, Canada, and its comparative analysis with H. parva Nielsen \& Christensen, 1959 (Enchytraeidae, Oligochaeta). - Zootaxa 3914: 185-194. https:// doi.org/10.11646/zootaxa.3914.2.8

Dózsa-Farkas, K., Ortmann-Ajkai, A. \& Horváth, F. (2015): New enchytraeid species (Oligochaeta: Enchytraeidae) from the Danube-Dráva National Park. - Acta Zoologica Academiae Scientiarum Hungaricae 61(4): 305-327.https://doi.org/10.17109/AZH.61.4.305.2015

Dózsa-Farkas, K., Felföldi, T. \& Hong, Y. (2015): New enchytraeid species (Enchytraeidae, Oligochaeta) from Korea. - Zootaxa 4006: 171-197. https://doi.org/10.11646/zootaxa.4006.1.9

Dózsa-Farkas, K. \& Felföldi, T. (2016): A new Fridericia species (Clitellata, Enchytraeidae) and the enchytraeid fauna of the Örség National Park (Hungary). - Opuscula Zoologica, Budapest 47(1): 65-72. https://doi.org/10.18348/opzool.2016.1.65

Erseus, C., Rota, E., Matamoros, L. \& De Wit, P. (2010): Molecular phylogeny of Enchytraeidae (Annelida, Clitellata). - Molecular Phylogenetics and Evolution 57: 849-858. https://doi.org/10.1016/j.ympev.2010.07.005

Folmer, O., Black, M., Hoen, W., Lutz, R. \& Vrijenhoek, R. (1994): DNA primers for amplification of mitochondrial cytochrome c oxidase subunit I from diverse metazoan invertebrates. - Molecular Marine Biology and Biotechnology 3: 294-299.

Healy, B. (1975): A description of five new species of Enchytraeidae (Oligochaeta) from Ireland. - Zoological Journal of the Linnean Society 56: 315-326. https://doi. org/10.1111/j.1096-3642.1975.tb00273.x

KAnE, R. A. \& Rollinson, D. (1994): Repetitive sequences in the ribosomal DNA internal transcribed spacer of Schistosoma haematobium, Schistosoma intercalatum and Schistosoma mattheii. - Molecular and Biochemical Parasitology 63: 153-156. https://doi. org/10.1016/0166-6851(94)90018-3

Martinson, S., Rota, E. \& Erséus, C. (2015): Revision of Cognettia (Clitellata, Enchytraeidae): re-establishment of Chamaedrilus and description of cryptic species in the sphagnetorum complex. - Systematics and Biodiversity 13(3): 257-277. https://doi.org/ 1080/14772000.2014.9865552014

MöLLER, F. (1971): Systematische Untersuchungen an terricolen Enchytraeiden einiger Grünlandstandorte im Bezirk Potsdam. - Mitteilungen aus dem Zoologischen Museum in Berlin 47: 131-167. https://doi.org/10.1002/mmnz.19710470114

Nurminen, M. (1977): Enchytraeidae (Oligochaeta) from the Grossglockner region of the Austrian Alps. - Annales Zoologici Fennici 14: 224-227. 
O'Connor, F. B. (1962): The extraction of Enchytraeidae from soil. Pp. 279-285. - In: MurPHY, P. W. (ed.): Progress in soil zoology. Butterworths Publishers, London.

RotA, E. (1995): Italian Enchytraeidae (Oligochaeta). I. - Bollettino di Zoologia 62: 183-231. https://doi.org/10.1080/11250009509356067

Schmelz, R. M. (1999): On the combined use of morphological and protein patterns in Enchytraeidae species level taxonomy: Example Fridericia discifera Healy, 1975. - Pedobiologia 43: 497-506.

Schmelz, R. M. (2003): Taxonomy of Fridericia (Oligochaeta, Enchytraeidae). Revision of species with morphological and biochemical methods. - Abhandlungen des NaturwissenschaftlichenVereins in Hamburg 38: 1-414. + 73 Figs.

Schmelz, R. M. \& Collado, R. (2010): A guide to European terrestrial and freshwater species of Enchytraeidae (Oligochaeta). - Soil Organisms 82(1): 1-176.

SchmidegG, E. (1938): Die Enchytraeiden des Hochgebirges der Nordtiroler Kalkalpen. - Naturwissenschaftlich-medizinischer Verein Innsbruck, $45 \mathrm{pp}$.

Tamura, K., Stecher, G., Peterson, D., Filipski, A. \& Kumar, S. (2013): MeGA6: Molecular evolutionary genetics analysis. Version 6.0. - Molecular Biology and Evolution 30: 2725-2729. https://doi.org/10.1093/molbev/mst197

Received October 28, 2016, accepted February 18, 2017, published March 30, 2018 